\title{
Forest ecosystem development after heavy deposition loads - case study Dübener Heide
}

\author{
C. Fürst, M. Abiy \& F. Makeschin \\ Institute for Soil Science and Site Ecology, \\ Dresden University of Technology, Germany
}

\begin{abstract}
Forest ecosystems in the New Lander (Germany) were impacted for more than one century by industrial emissions. The deposition amount has decreased since the middle of the 1980s due to technological progress and closing of main emitters. In the research project ENFORCHANGE (www.enforchange.de), the impact of past industrial depositions on forest ecosystems is assessed in two model regions, and approaches how to integrate deposition residuals into forest management are developed. The here presented model region Dübener Heide is a ca. $300 \mathrm{~km}^{2}$ large forest area in the industrial triangle Leipzig-Halle-Bitterfeld, which is one of the most polluted regions in the New Lander. A total deposition

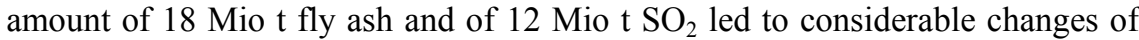
site properties, forest growth and health. The actual investigations in Dübener Heide revealed that the historical deposition impact still results in a spatial differentiation of forest growth conditions: nowadays, Dübener Heide can be divided into two parts with different impact level and intensity. Verifiable fly ash influence with high $\mathrm{pH}$ values and nutrient potential is limited to a zone of maximally $8-15 \mathrm{~km}$ distance to the former emitters, whereas $\mathrm{SO}_{2}$ impacted the total $300 \mathrm{~km}^{2}$ area, but its effects are no longer detectable. This spatial differentiation is relevant for tree species choice in the future: the heavily fly ash impacted sites are characterized by ample regeneration and growth of noble hardwood species and European beech, whereas the not measurably fly ash influenced sites are more or less suitable for Scots Pine and Oak. The prediction of the long-term development of the site potential and tree species suitability on heavily fly ash affected sites under different climate change scenarios are part of ongoing studies.
\end{abstract}

Keywords: forest ecosystem development, fly ash deposition, $\mathrm{SO}_{2}$ deposition, forest growth and health, site potential, forest management planning. 


\section{Introduction - case study Dübener Heide and assessment of former deposition loads (ENFORCHANGE)}

\subsection{Deposition history in the model region Dübener Heide}

For more than one century, forest ecosystems in the New Lander were heavily impacted by industrial depositions. In the industrial triangle Leipzig-HalleBitterfeld, one of the most polluted regions of the New Lander, this deposition originated from unfiltered brown-coal combustion and exhalations from chemical industry (Fürst et al. [5]). The extreme alteration of the natural conditions, which lasted until the early 1990s, is still impacting the site properties and vegetation dynamics and must be considered in actual forest management. Zooming into the region Leipzig-Halle-Bitterfeld and taking the Dübener Heide - the most important regional forest area - as an example, the historically documented deposition amounted from 1910 - 2000 to 18 Mio t fly

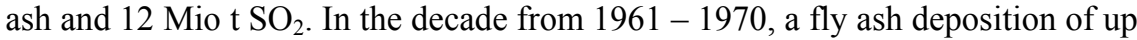
to $3-8 \mathrm{t} / \mathrm{ha} *$ a is reported by Lux [21, 24], Neumeister et al. [30], Nebe et al. [31] and Klose and Makeschin [13]. To demonstrate the extend of deposition impact on the forest soils: $\mathrm{pH}(\mathrm{KCl})$ values in the humus layer and upper mineral horizon of the regional forest soils (mainly poor sandy brown soils and podzols) increased in that period from originally 3-4 up to 7-9 and a base saturation of up to $100 \%$ is still detectable (Fritz and Makeschin [3]). From the 1980s on, the introduction of fly ash filters lead to a more or less acidic deposition regime $\left(\mathrm{NO}_{\mathrm{x}}, \mathrm{SO}_{2} / \mathrm{SO}_{\mathrm{x}}\right)$. After 1989, a strong reduction of fly ash emission went along with raising atmospheric $\mathrm{N}$ deposition in a magnitude of $28-45 \mathrm{~kg} / \mathrm{ha} * \mathrm{a}$ and changed completely the regional deposition characteristics (Hüttl and Bellmann [11], Marquardt et al. [29], Gauger et al. [8]).

Lux [21, 24] and Lux and Stein [26] have shown that the Dübener Heide deposition situation is characterized by a wind direction and distance dependent gradient (Fig 1), starting in the eastern part of the forest mainly at the power plants and chemical industries clustered in Bitterfeld and its surroundings (Gräfenhainichen, Zschornewitz). The different deposition fractions $\mathrm{SO}_{2}$ and fly ash, which contains "black" (tertiary) carbon, alkali / earth alkali metal salts, heavy metals and silicium compounds, were distributed along this gradient according to their aggregate state and particle size (Lux [22, 24], Niehus and Brüggemann [32], Magiera and Stryszcz [27], Stryszcz [35]).

Stein [34] and Lux [24] used a visual classification of forest decline for distinguishing up to five deposition zones along this gradient, where the differentiation between zone $1 \mathrm{a}$ and $1 \mathrm{~b}$ (zones of highest intensity) was given up later on. Lux [21] and Lux and Pelz [25] proposed to take these deposition zones as basis for forest management planning. The deposition zones were defined on the basis of a sample plot supported evaluation system: visible crown damages (forest decline classes) in 150 plots in medium aged Scots pine stands were assessed on single tree level, then compiled for stand level and "regionalized" by subsequent spatial aggregation of comparable stands to the deposition zones. Each deposition zone was assumed to be homogenous 


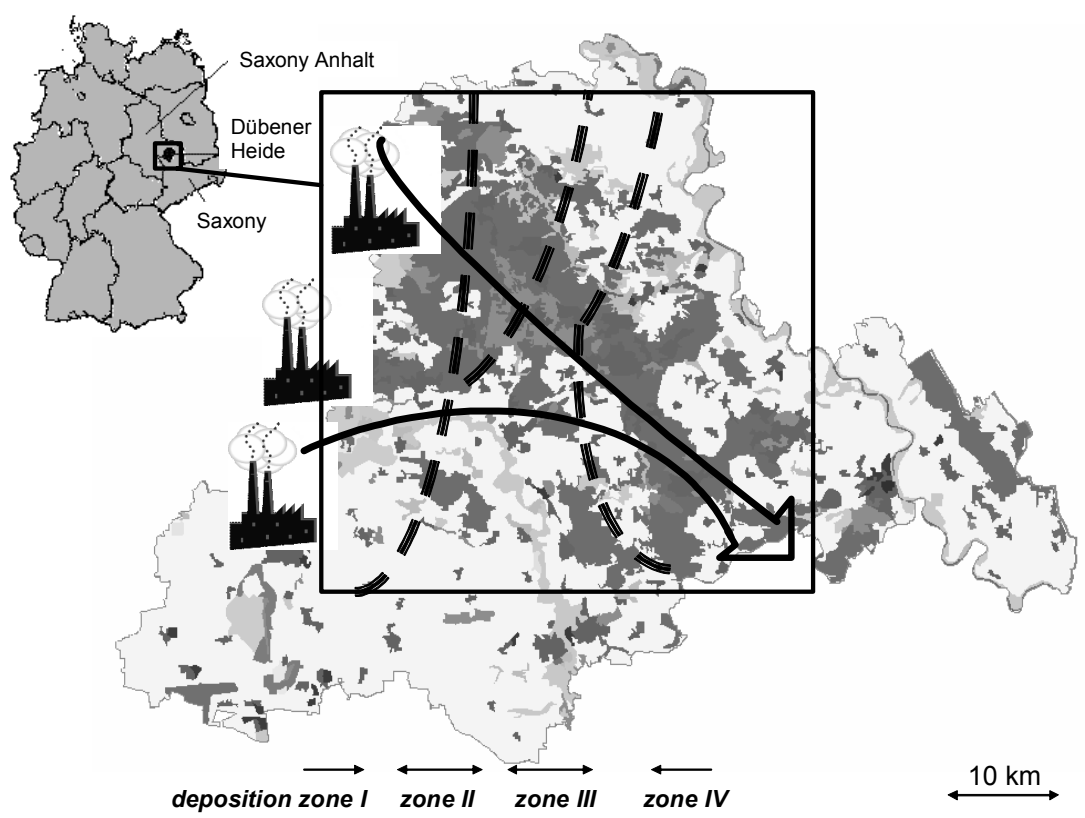

Figure 1: $\quad$ Schematic overview on the localization of Dübener Heide (black square) and the regional deposition gradient (black arrow), starting at the industrial sites in the East and following the dominant wind direction (map basis: CORINE LANDCOVER (CLC) 2000). The deposition zones are marked with scattered lines.

considering the deposition impact on forest growth and health, on specific risks and on possible silvicultural strategies and economic output. In deposition zone 1 e.g., Scots pine, the regionally dominating tree species, was heavily threatened by the alkaline fly ash deposition or dropped even totally out. In consequence, conversion efforts were concentrated to this zone and management intensity was reduced to deposition damage driven harvesting.

At the late 1980s, Herpel et al. [10] documented at heavily fly ash influenced sites a decrease of $\mathrm{pH}(\mathrm{KCl})$ of 0.4 units and base saturation decrease of $17 \%$ compared to the 1970s. This went along with incipient installations of fly ash filters at the main regional emitters. From 1988 to 2000, a further reduction of $0.7 \mathrm{pH}$-units was reported by Kurbel [18]. In the long run, a rapprochement of the site properties to the original regional characteristics is expected (Kopp [16], Kopp and Jochheim [17]).

As a result of deposition reduction, the health state of the forest and especially of Scots pine stands improved considerably since the 1990s. Actually, ample regeneration of noble hardwoods and European beech can be observed especially in the extremely fly ash influenced parts of the Dübener Heide. This however, might be a temporary phenomenon, whose sustainable development and ability 
to be integrated into regional silviculture must be evaluated beyond the background of the described re-acidification tendency.

\subsection{ENFORCHANGE - assessment and evaluation of former deposition loads}

"ENFORCHANGE" (Environment and Forests under Changing Conditions, www.enforchange.de) is a research project supported by the Federal Ministry of Education and Research (BMBF, Germany), which intends to assess the longterm effects of former depositions in two model regions in the New Lander, among them Dübener Heide. Based on this assessment, approaches are derived for better respecting this special situation and its expected impact on a number of forest services in forest management.

ENFORCHANGE started with the NULL-hypothesis, that the forest sites in the historically documented deposition zones in Dübener Heide are still different considering (a) their potentials such as nigh nutrient availability and (b) specific risks such as heavy metal release, which are relevant for forest management decisions (Makeschin and Fürst [28]). Furthermore, it was assumed that at least forest growth is still impacted by the spatial differentiation of the site properties along the former deposition gradient. Finally, ENFORCHANGE intended to model and regionalize ongoing ecosystem processes as basis for process-oriented forest management decisions.

Figure 2 resumes the ENFORCHANGE approach, how to come to an information pool providing spatially explicit time series data as basis for modelling and regionalization of ongoing ecosystem processes (Fürst et al. [5, 6]).

A number of 12 key plots was installed in the Dübener Heide along the historically documented deposition gradient. The key plots represent the major (terrestrial) soil type and stand type combinations in the region. They were preferably chosen at sites, where information from former deposition monitoring, forest health monitoring or growth and yield field trials could be involved. At the key plots, chemical and physical site properties are measured depth level-wise with focus on the humus layers and the upper mineral horizons and forest growth and yield characteristics are assessed.

The key plots were installed permanently for the total project duration, i.e. their geographical coordinates are documented, and geo-referenced to available GIS-information (site maps / geology, topography, etc.). Missing information, e.g. considering stand type development in a distinct deposition zone and on a distinct site type but in different age classes was collected at satelite plots, which are not permanently installed. Last but not least, field assessment of former fly ash deposition was carried out at the key plots and in a regular sample grid with two different grid densities $\left(1 * 1 \mathrm{~km}^{2}\right.$ and $\left.4 * 4 \mathrm{~km}^{2}\right)$ as interface to the regionalization of the actually detectable deposition load. Here, ferrimagnetic susceptibility was used, which describes the amount of magnetizable iron-oxides, a distinctive component of fly ash from coal combustion (Fürst et al. [4]). Ferrimagnetic susceptibility was also measured depth-level wise with focus on the humus layers and the upper mineral horizons. 


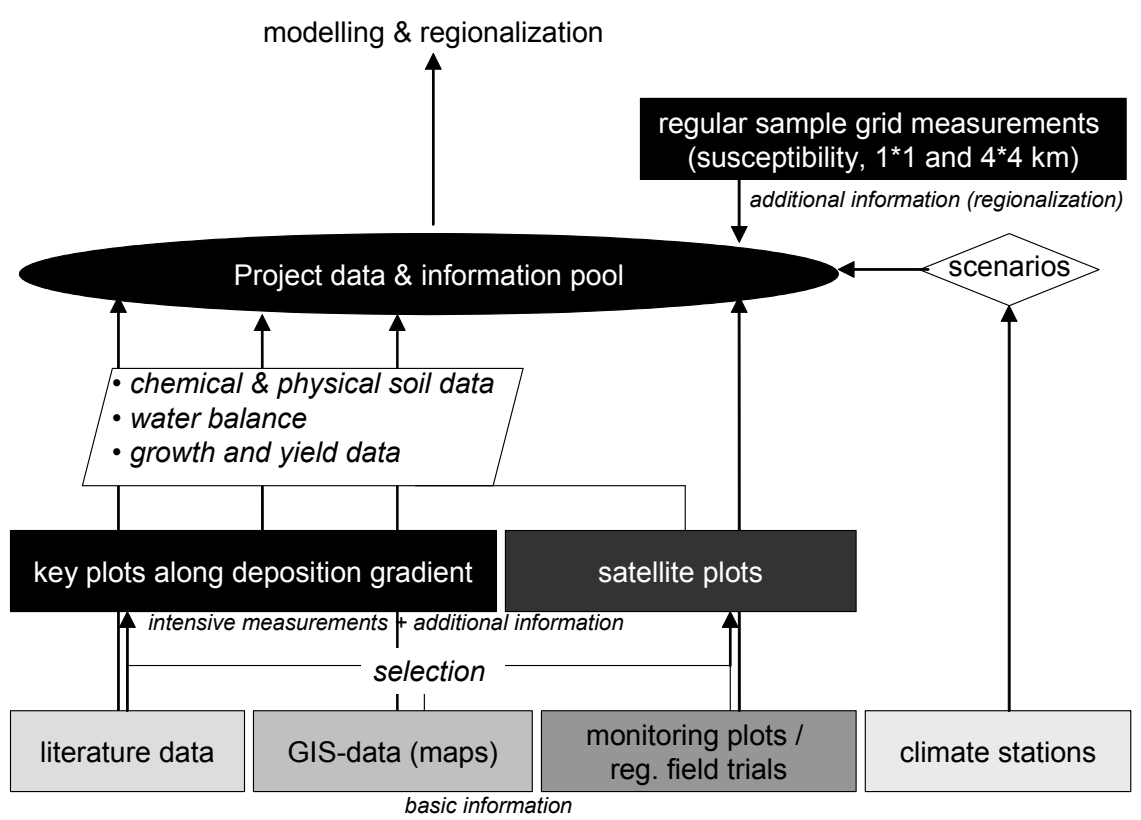

Figure 2: $\quad$ System of information bundling in ENFORCHANGE consisting of regionally available data, complementary information from own measurements and results from monitoring and regionalization.

Finally, information from further regional monitoring and survey plots (Level-I, Level-II monitoring, permanent soil monitoring sites, forest growth and yield field trials, climate stations), data from literature analysis and available GIS-data were integrated into the ENFORCHANGE information pool.

\section{Long-term deposition impact on forest ecosystems - some first results}

\subsection{Deposition impact on the site potential}

The analysis of chemical and hydrological site properties at the 12 key plots and the ferrimagnetic susceptibility based screening revealed that the differences along the historical deposition gradient still exist. They are mainly induced by former fly ash deposition. $\mathrm{SO}_{2}$ deposition impact could not be detected anymore. The former deposition zones are still traceable by differences in the equipment with nutrients, especially base cations (Fig. 3a), by differences in physical humus properties, such as content of mineral matter in the humus layer (Klose et al. [14], Koch et al. [15]) and by different levels of ferrimagnetic susceptibility (Fig. 3b). Though, the borderlines of the former forest decline classification 
based spatial stratification and the actual spatial stratification according to chemical and physical characteristics are not completely identical.

Fig. 3a shows results from the multiple-regression based regionalization of the actual base saturation in the humus layer, Fig. $3 \mathrm{~b}$ provides results from the kriging based regionalization of ferrimagnetic susceptibility (volume susceptibility) as indicator for the verifiability of fly ash deposition in the Dübener Heide.
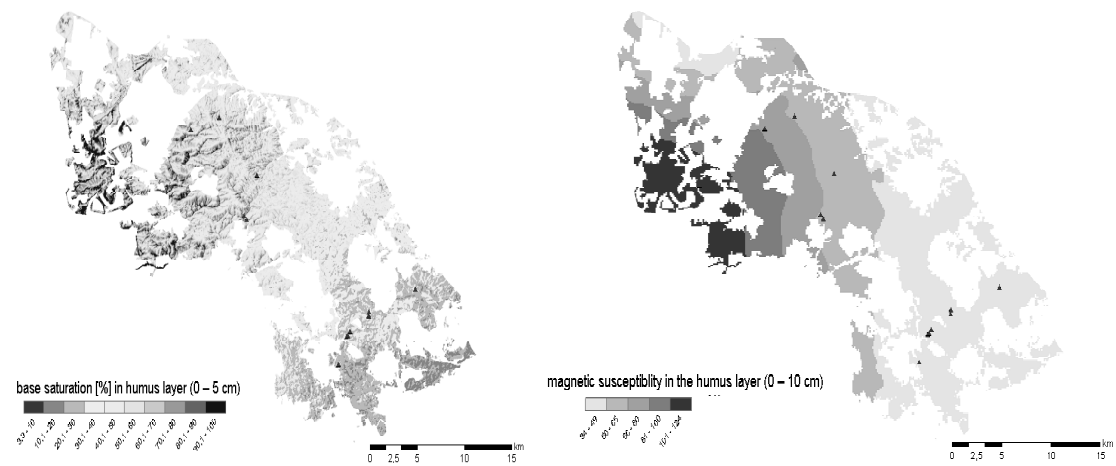

Figure 3: a (left): Regionalization of base saturation in the humus layer. $\mathrm{b}$ (right): Regionalization of magnetic susceptibility in the humus layer.

Fig. 3a and $\mathrm{b}$ reveal major differences between the immediate vicinity to the former emitters in the eastern part of Dübener Heide and the western part, which is farthest from the emission sources. A differentiation of the part in between is possible, but the absolute values of the measured chemical and physical properties and their high variability do not support a clear separation into several deposition zones.

Actually, site potential differences, which are indeed relevant for differentiated forest management strategies, can only be ascertained for two zones: a "high influence zone" in up to $8-15 \mathrm{~km}$ distance to the former emitters and a "low influence zone" in more than $8-15 \mathrm{~km}$ distance. Fig. 4 (next page) introduces the results of a cluster analysis of the magnetic susceptibility values in the humus layers of the 12 key plots. The plots in a distance up to 8 and up to $15 \mathrm{~km}$ differentiate clearly from the rest. This finding is supported by similar cluster analysis results of further chemical and physical humus properties. The "high influence zone" is characterised by high base cation availability and base saturation in the humus layers, indicating a considerable nutrient pool far beyond from the natural level. The stock of extractable $\mathrm{Ca}$ in the humus layer and upper mineral soil until a depth of $30 \mathrm{~cm}$ e.g., reaches up to $4,000 \mathrm{~kg} / \mathrm{ha}$ in the zone up to $8 \mathrm{~km}$ distance to the former emitters (Fritz et al. [3]). This is 10 to 20 times higher compared to the plots in a distance of $30 \mathrm{~km}$, which are farthest to the former emitters and whose chemical properties represent more or less the original regional potential. Based on first tentative extrapolations, $\mathrm{pH}$ values might approximate to the original regional values in a time period of around 30 
50 yrs. Until now, it is however not foreseeable until when the high base cation potential can still be considered as silviculturally relevant factor. Considering the physical humus properties, a smaller fine pore volume going along with higher air capacity can be stated (Hartmann et al. [9]). In the "low influence zone", humus properties are much more dependent from the original site characteristics and the stand type.

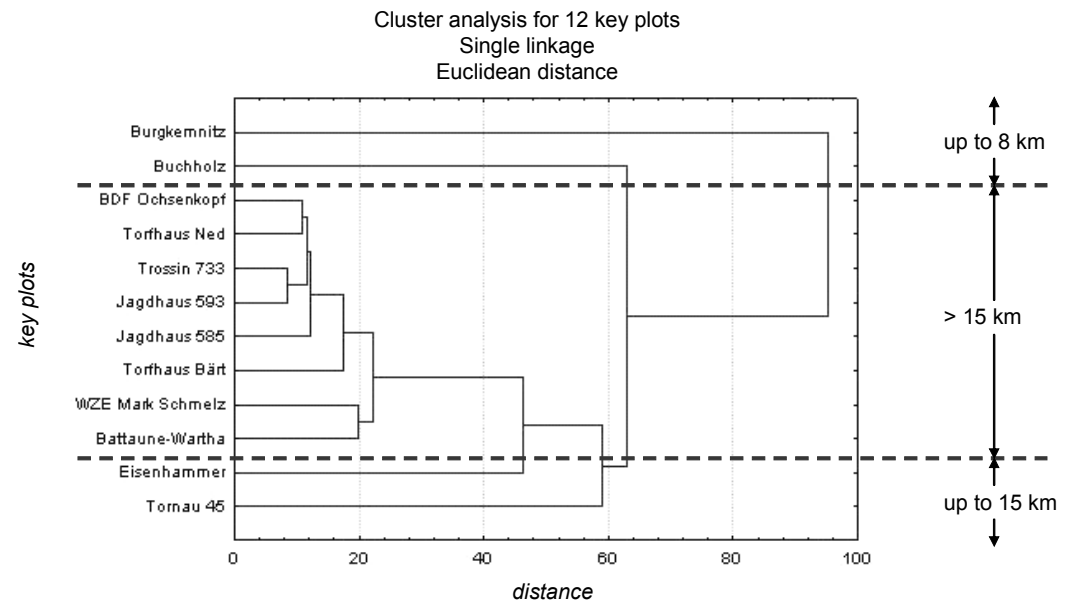

Figure 4: Results from a cluster analysis of magnetic susceptibility (laboratory measurement, humus layer) at the 12 key plots.

One of the major challenges for future management of the forests in Dübener Heide is the change of the regional climate. The down-scaling of global climate change scenarios for Dübener Heide proved that a reduction of the mean annual precipitation of up to $100 \mathrm{~mm}$ and an increase of the mean annual temperature of up to $3.5^{\circ} \mathrm{C}$ can be expected. Even worse, the water deficiency during the summer period is estimated to become aggravated, which affects especially the regionally dominating poor sandy soils (Bernhofer et al. [1], Franke and Köstner [2]). Beyond that background, results from effects of fly ash deposition on hydrological properties of the humus layers become important. Fly ash can not only be considered as multi-nutrient fertilizer (Fürst et al. [7]), but can also impact the properties of the regionally dominating moder-raw humus forms with their high hydrophobicity. In contrast to former findings (Thomasius et al. [36], Katzur et al. [12]), Hartmann et al. [9] revealed that fly ash reduces the water repellency and hydrophobicity of the humus layers in the "highly influenced zone" and increases the water conductivity. At the same time, the available water for plant growth, expressed by the field moisture capacity becomes smaller due to the fly ash caused decrease of the fine pore volume. Additionally, a tendencially decreased depth of the root zone due to high nutrient availability at the humus layer and upper mineral horizon at fly ash influenced sites might amplify the future risk of drought stress (Thomasius et al. [36], Koch et al. [15], Klose et al. [14]). 


\subsection{Deposition impact on forest growth}

Forest health and consequently growth were extremely affected by the former depositions. Comparing different time strata, (a) the late 1960s until 1980, (b) the 1980s, (c) the time from 1940 until 1991 and (d) the mid of the 1970s until 1991, Lux [23] and Hüttl and Bellmann [11] proved the enormous impact of the industrial emissions on the forest development in Dübener Heide. Fig. 5 compares the reaction in radial increment of Scots pine for the four time strata at the historically documented four deposition zones.

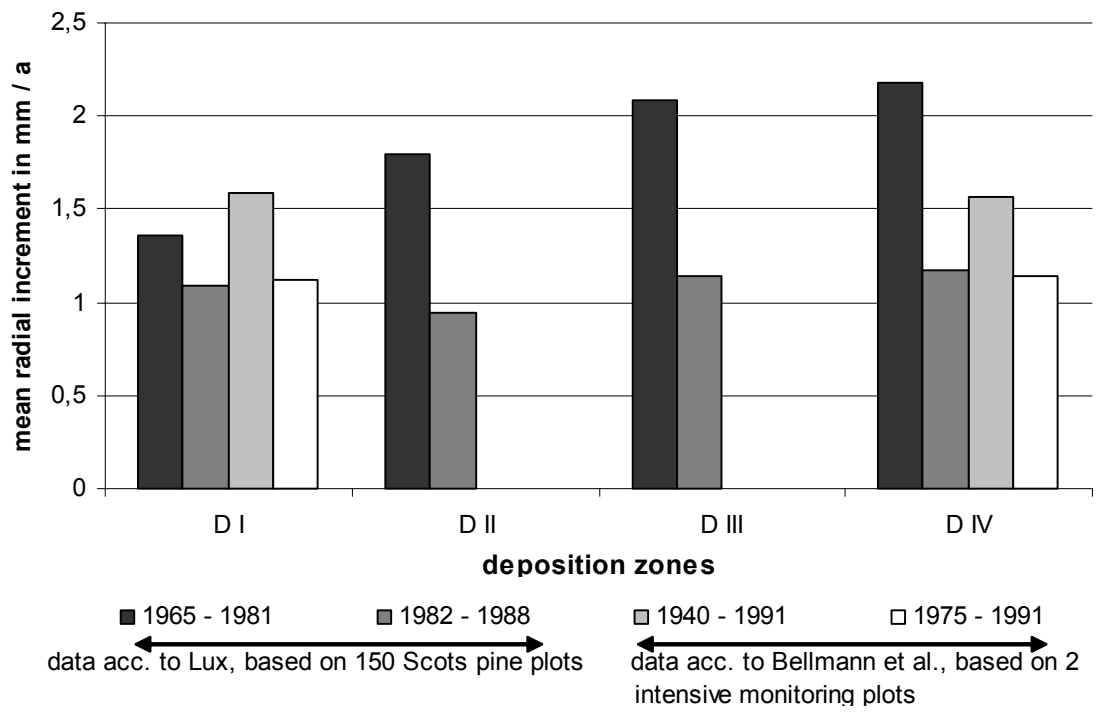

Figure 5: Reduction of the radial increment of Scots pine in four different time strata. In the $1980 \mathrm{~s}$, first fly ash filters were installed, whereas $\mathrm{SO}_{2}$ emission was not yet stopped. Consequently, emission impact on forest health and growth became even worse (Lux [23], Hüttl and Bellmann [11]).

In tendency, radial increment was negatively impacted by the depositions at Dübener Heide. This resulted mainly from the extremely high $\mathrm{SO}_{2}$ deposition: from 1965 to 1981 , deposition showed the expected spatially differentiated impact on the mean radial increment, with decreasing intensity from deposition zone I (DI) to deposition zone IV (DIV). But afterwards, in the period 1982 1988, the spatial differentiation seemed to disappear. This period was characterized by beginning fly ash filtering, where at the same time, $\mathrm{SO}_{2}$ deposition even increased. From the 1990s on, the last power plants were closed or were equipped with modern fly ash and $\mathrm{SO}_{2}$ filtering techniques.

Comparing the radial increment tendencies between 1940-1991 and 19751991, where data were only available for zone I (DI) and zone IV (DIV), it can 
else be demonstrated that the influence of the deposition on differences in mean radial increment does not show the extreme spatial differentiation, which was assumed in the 1960s, the time, were the deposition zones were defined. The height growth tendencies followed comparable trends. This supports the impression that $\mathrm{SO}_{2}$ deposition, which affected the forest over a wide area and not fly ash deposition with its more or less local importance, was the relevant agent. Of course, forests in the immediate vicinity of the former emitters reacted first and thus supported the stratification into four deposition zones at least in the first period of heavy deposition (Lux [22]).

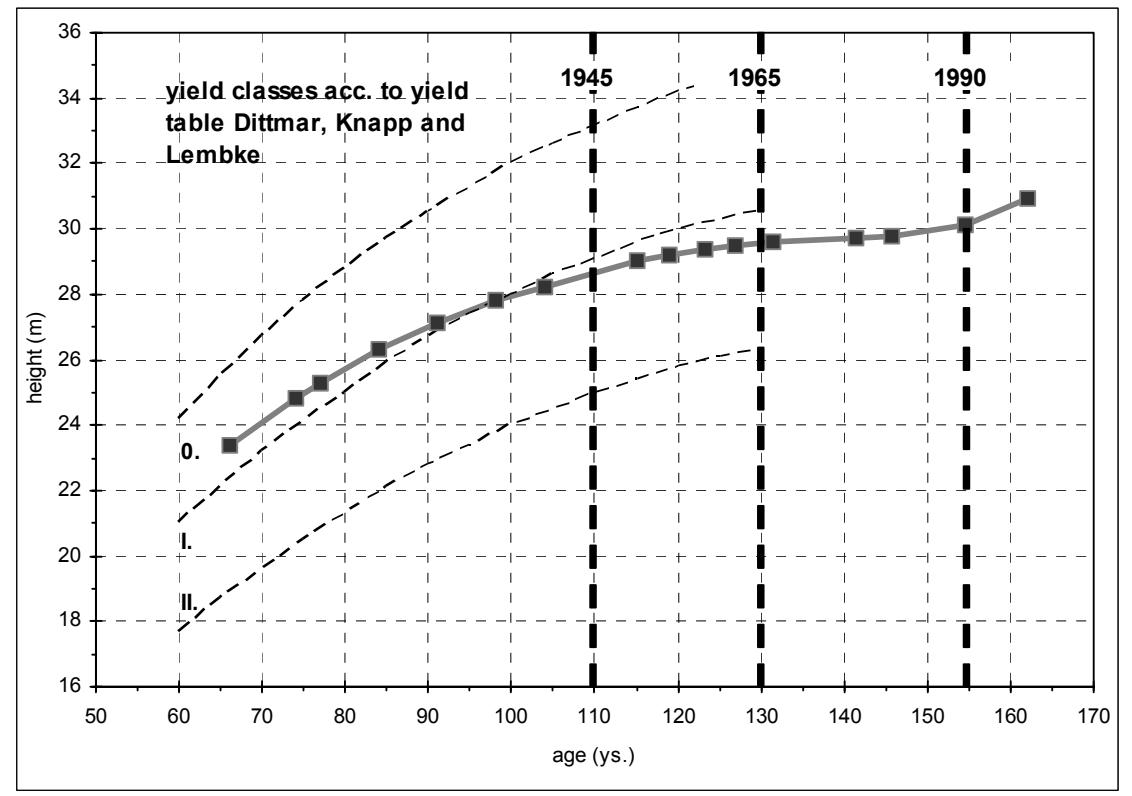

Figure 6: Trends of height growth development of a Scots pine stand (plot Tornau 45, $15 \mathrm{~km}$ distance to the emitters) before, during and after the deposition period. In the period from 1965-1990, a stagnation in height growth can be shown. After 1990, Scots pine restarted to grow in an age of even 155 yrs [data source: investigations of the former State Forest Research Centre Flechtingen, Saxony-Anhalt, 2005).

Investigations from intensive forest growth monitoring plots have proved that height growth of Scots pine recovered after the 1990s (Fig. 6).

Ongoing measurements at the ENFORCHANGE key plots show that nowadays, height and diameter growth of forests in Dübener Heide follow the general trend to be superior to the benchmark data in the regionally valid growth and yield tables (Pretzsch et al. [33]). This applies to all relevant stand types and especially for the regionally dominating Scots pine stands. 


\section{Conclusions and preview}

After stopping the heavy depositions, the situation has been improved considerably for the regional forest ecosystem Dübener Heide. On the other hand, it should be highlightened that at least fly ash deposition effects can not only be considered as damaging factor. Fly ash deposition increased the available nutrient potential in the humus layers and the upper mineral horizons in the dominating poor sandy soils of Dübener Heide (Fürst et al. [5]). Furthermore, fly ash deposition tends to result in improved hydrological properties of the humus layers, a fact which gains in importance facing the problem of reduced water availability in the future. A visible consequence of the fly ash deposition caused improvement of the site potential is the ample noble hardwood and European beech regeneration, which can be observed in the zone of 8-maximally $15 \mathrm{~km}$ distance to the former emitters. Its potential to be integrated into silvicultural concepts must be discussed quite critically: considering the ongoing re-acidification of the fly ash influenced sites and the uncertainty how long the artificially increased nutrient potential is available for plant growth, the future regional suitability especially of noble hardwoods on sandy soils is doubtful. Furthermore, results of climate change modelling and regionalization suggest a severe decrease of regional precipitation, which amounts to almost $20-25 \%$ of the actual rainfall. This supports a turn back to drought resistant tree species such as Scots pine and Oak, which however are not able to benefit from the actually increased nutrient potential.

Some first results on the analysis of heavy metal loads in the regional forest sites as a result of fly ash deposition revealed total net values which exceed by far (up to 5-times) the thresholds given by national regulations for heavy metal values such as LABO [19]. Critical values however are more or less restricted to the immediate vicinity of the former emitters, where still high $\mathrm{pH}$-values confine the mobility of endangering heavy metals and limit their possible discharge into the ground water. Prolonging the actual re-acidification tendency of the regional sites of $0.7 \mathrm{pH}$ units within around 12-15 years after the closure of the former emitters and the additional acidification impact of regional N-deposition, a supposable potential of ground water quality impact can be expected in the next 50 ys. Conversion of the Scots pine and Oak dominated forests with European beech could be a countermeasure. Facing the problem of reduced water availability, this demands however for adapted conversion and transformation concepts with respect to the potential of different stand structures and tree species mixture types to reduce the evapotranspiration.

Therefore, model coupling approaches in ENFORCHANGE, linking forest growth (SILVA) with nutrient and water balance (BALANCE) and impact of forest structure and tree species composition on stand climate (HIRVAC) help to test and consider the above outlined multiple aspects in regional silvicultural planning. The future challenge will consist in using the still existing deposition driven site potentials under new climate conditions and to find strategies for responding on possible environmental risks. 


\section{References}

[1] Bernhofer, C., Goldberg, V., Surke, M., Fischer, B., Meteorologie Regionalisierung von Klima/Bestandesklimamodellierung, ENFORCHANGE - Wälder von heute für eine Umwelt von morgen, Statusbericht des Verbundes, Eigenverlag, 50-62, 2007.

[2] Franke, J., Köstner, B., Effects of recent climate trends on the distribution of potential natural vegetation in Central Germany, International journal of biometeorology 52(2), 139-147, 2006.

[3] Fritz, H., Makeschin, F., Chemische Eigenschaften flugaschebeeinflusster Böden der Dübener Heide, Arch. Naturschutz u. Landschaftsforsch. 46(3), 105-120, 2007.

[4] Fürst, C., Abiy, M., Makeschin, F., Regionalization of former fly ash deposition in forest systems in the industrial triangle Leipzig-HalleBitterfeld - a pre-test, Forestry, (submitted).

[5] Fürst, C., Lorz, C., Makeschin, F., Development of forest ecosystems after heavy deposition loads considering Dübener Heide as an example challenges for a process-oriented forest management planning, SI "Meeting the challenges for process-oriented forest management" Forest Ecology and Management 248(1-2), 6-16, 2007.

[6] Fürst, C., Lorz, C., Abiy, M., Makeschin, F., Fly ash deposition in NorthEastern Germany and consequences for forest management, Contributions to Forest Sciences, Ulmer, 50-63, 2006 a.

[7] Fürst, C., Makeschin, F. Comparison of Wood Ash, Rock Powder, and Fly Ash - a review, Contributions to Forest Sciences, Ulmer, 63-81, 2006 b.

[8] Gauger, T., Anshelm, F., Schuster, H., Eirsman, J.W., Vermeulen, A.T., Draaijers, G.P.J., Bleeker, A., Nagel, H.-D., Mapping of ecosystem specific long-term trends in deposition loads and concentrations of air pollutants in Germany and their comparison with Critical Loads and Critical Levels, Part 1: Deposition Loads 1990-1999. Final Report 29942210 Umweltbundesamt, 207 p., 2002.

[9] Hartmann, P., Fleige, H., Horn, R., Flugascheeinfluss auf Böden in der Dübener Heide - Physikalische Eigenschaften, Hydrophobie und Wasserhaushalt, Arch. Naturschutz u. Landschaftsforsch. 46(3), 79-103, 2007.

[10] Herpel, J., Heinze, M., Fiedler, H.J., Veränderungen von Boden und Vegetation in Kiefernbeständen der Dübener Heide zwischen 1966 und 1990. Arch. Naturschutz u. Landschaftsforsch. 34(1), 17-41, 1995.

[11] Hüttl, R. F.; Bellmann, K. (eds.), Changes of Atmospheric Chemistry and Effects on Forest Ecosystems - A Roof Experiment Without Roof. Nutrients in Ecosystems 3, Springer Berlin, Heidelberg, New York, 384 p., 1999.

[12] Katzur, J., Strzyszcz, Z., Tölle, R., Liebner, F., Magnetisches Eisen als Tracer für die Bestimmung der Homogenität von Boden-Asche-Gemischen bei der Melioration extrem sauerer Kippböden. Archiwum Ochrony Srodowiska 24, 83-93, 1998. 
[13] Klose, S., Makeschin, F., Chemical properties of forest soils along a fly ash deposition gradient in Eastern Germany. Europ. J. Forest Res. 123, 3-12, 2004.

[14] Klose, S., Tölle, R., Bäucker, E., Makeschin; F., Stratigraphic Distribution of Lignite-Derived Atmospheric Deposits in Forest Soils of the upper Lusatian Region, East Germany. Water, Air and Soil Pollution 142, 3-25, 2002.

[15] Koch, J., Klose, S., Makeschin, F., Stratigraphic and Spatial Differentiation of Chemical Properties in Long-term Fly Ash Influenced Forest Soils in the Dübener Heide Region, NE-Germany. Forstw. Cbl. 121, 157-170, 2002.

[16] Kopp, D., Zusammenwirken von Standort und Vegetation bei der Erkundung des Zustandswandels von Waldnaturräumen in nordostdeutschen Tiefland. Arch. Naturschutz u. Landschaftsforsch. 42(1), 1-49, 2003.

[17] Kopp, D., Jochheim, H., Forstliche Boden- und Standortsdaten des Nordostdeutschen Tieflands als Datenbasis für die Landschaftsmodellierung. Kessel Remagen-Oberwinter, 207 p., 2002.

[18] Kurbel, R., Untersuchungen zur Mobilität und zum Gesamtgehalt von Schwermetallen mittels Säulenversuch und sequentieller Extraktion für zwei Standorte der Dübener Heide. Diploma thesis Dresden University of Technology, 65 p., 2002.

[19] LABO (Bund-Länder-Arbeitsgemeinschaft Bodenschutz), Hintergrundwerte für anorganische und organische Stoffe in Böden, 3. überarbeitete und ergänzte Auflage, Eigenverlag, 59 p., 2003.

[20] Lux, H., Ergebnisse von Zuwachsuntersuchungen (Bohrspananalysen) im Rauchschadensgebiet Dübener Heide, Arch. Forstwes. 11, 1103-1121, 1964.

[21] Lux, H., Die großräumige Abgrenzung von Rauchschadenszonen im Einflussbereich des Industriegebietes um Bitterfeld, Wiss. Z. Techn. Univers. Dresden 14, 433-442, 1965.

[22] Lux, H., Beitrag zur Trennung des Schadanteils gleichzeitig auf die Waldvegetation einwirkender Abgasquellen, Wiss. Z. Techn. Univers. Dresden 15, 1533-1535, 1966.

[23] Lux, H., Zur Beeinflussung des Oberbodens von Kiefernbeständen durch basische Industriestäube. Wiss. Z. Techn. Univers. Dresden 23, 915-920, 1974.

[24] Lux, H., Ausbreitung und Berechung (Immissionen). in Däßler, H.G (ed.).: Einfluss von Luftverunreinigungen auf die Vegetation: Ursachen Wirkung - Gegenmaßnahmen, Fischer Jena, 26-33, 1976.

[25] Lux, H., Pelz, E., Schadzone und Schadstufe als Klassifizierungsbegriffe in rauchgeschädigten Waldgebieten. Forstwirtschaft 18, 245-247, 1968.

[26] Lux, H., Stein, G., Die forstlichen Immissionsschadgebiete in Lee des Ballungsraumes Halle und Leipzig. Hercynia N.F., 352-354, 1977.

[27] Magiera, T., Strzyszcz, Z., Ferrimagnetic Minerals of Anthropogenic Origin in Soils of some Polish National Parks. Water, Air and Soil Pollution 124, 37-48, 1999. 
[28] Makeschin, F., Fürst, C., Influence of vectored changes of environmental factors (climate, site and human beings) on land-use systems - example forest land-use (ENFORCHANGE), Annals of Agrarian Science 5(2), ISSN 1512-1887, 86-91, 2007.

[29] Marquardt, W., Brüggemann, E., Auel, R., Herrmann, H., Möller, M., Trends of pollution in rain over East Germany caused by changing emissions, TELLUS 53 B, 529-545, 2001.

[30] Neumeister, H., Franke, C., Nagel, C., Peklo, G., Zierath, R., Peklo, P., Immissionsbedingte Stoffeinträge aus der Luft als geomorphologischer Faktor. Geoökodynamik 12, 1-40, 1991.

[31] Nebe, W., Pommnitz, M., Jeschke, J., Aktueller Standortszustand und Waldumbau im nord-westsächsischen Tiefland. Forst und Holz 56(1), 3-8, 2001.

[32] Niehus, B., Brüggemann, L., Untersuchungen zur Deposition luftgetragener Stoffe in der Dübener Heide. Beitr. Forstwirtsch. u. Landsch. Ökol. 29(4), 160-163, 1995.

[33] Pretzsch, H., Rötzer, T., Moshammer, R., Waldwachstumsreaktionen und Systemanalyse, ENFORCHANGE - Wälder von heute für eine Umwelt von morgen, Statusbericht des Verbundes, Eigenverlag, 80-91, 2007.

[34] Stein, G., Der forstliche Zustandsvergleich - eine Diagnosemethode in rauchgeschädigten Waldgebieten. Wiss. Z. TU Dresden 14, 1043-1049, 1965.

[35] Stryszcz, Z., Heavy Metal Contamination in Mountain Soils of Poland as a Result of Anthropogenic Pressure. Biology Bulletin 26, 722-735, 1999.

[36] Thomasius, H.; Wünsche. M.; Selent, H., Bräunig, A., Wald- und Forstökosysteme auf Kippen des Braunkohlenbergbaus in Sachsen - ihre Entstehung, Dynamik und Bewirtschaftung - Schriftenreihe d. Sächs. Landesanst. f. Forsten 17, 68 p., 1999. 